Prepared for the U.S. Department of Energy

under Contract DE-AC05-76RL01830

\title{
PNNL Coal Gasification Research
}

\author{
D Reid JE Cabe \\ MD Bearden
}

July 2010

Pacific Northwest

NATIONAL LABORATORY

Proudly Operated by Battelle Since 1965 


\section{DISCLAIMER}

This report was prepared as an account of work sponsored by an agency of the United States Government. Neither the United States Government nor any agency thereof, nor Battelle Memorial Institute, nor any of their employees, makes any warranty, express or implied, or assumes any legal liability or responsibility for the accuracy, completeness, or usefulness of any information, apparatus, product, or process disclosed, or represents that its use would not infringe privately owned rights. Reference herein to any specific commercial product, process, or service by trade name, trademark, manufacturer, or otherwise does not necessarily constitute or imply its endorsement, recommendation, or favoring by the United States Government or any agency thereof, or Battelle Memorial Institute. The views and opinions of authors expressed herein do not necessarily state or reflect those of the United States Government or any agency thereof.

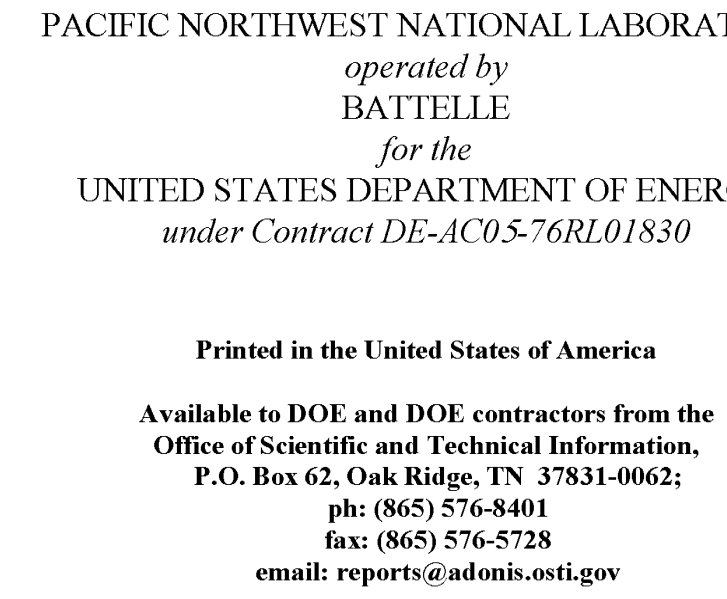

Available to the public from the National Technical Information Service, U.S. Department of Commerce, 5285 Port Roy al Rd., Springfield, VA 22161 ph: (800) 553-6847 fax: (703) 605-6900 email: orders@ntis.fedworld.gov online ordering: http://www.ntis.gov/ordering.htm 


\title{
PNNL Coal Gasification Research
}

\author{
D Reid \\ JE Cabe \\ MD Bearden
}

July 2010

Prepared for

the U.S. Department of Energy

under Contract DE-AC05-76RL01830

Pacific Northwest National Laboratory

Richland, Washington 99352 



\section{Abstract}

This report explains the goals of PNNL in relation to coal gasification research. The long-term intent of this effort is to produce a syngas product for use by internal Pacific Northwest National Laboratory (PNNL) researchers in materials, catalysts, and instrumentation development.

Future work on the project will focus on improving the reliability and performance of the gasifier, with a goal of continuous operation for 4 hours using coal feedstock. In addition, system modifications to increase operational flexibility and reliability or accommodate other fuel sources that can be used for syngas production could be useful. 



\section{Acknowledgments}

The authors gratefully acknowledge the financial assistance of a Laboratory Directed Research and Development (LDRD) project from Pacific Northwest National Laboratory ${ }^{1}$ (PNNL). All research herein was performed at the Integrated Environmental Technologies (InEnTec) facility in Richland, WA.

James Cabe was the project manager and a source of great knowledge and guidance. Stanley L.

Owsley Jr., Mark D. Bearden, Robert J. Robertus, Mike Dodson, and Michael L. Elliott were instrumental in the initial design and construction effort.

\footnotetext{
${ }^{1}$ Proudly Operated for the U.S. Department of Energy (DOE) by Battelle Memorial Institute
} 



\section{Acronyms and Abbreviations}

${ }^{\circ} \mathrm{F}$

$\Delta \mathrm{H}^{\mathrm{o}}$

$\tau$

ASTM

BTU

$\mathrm{CH}_{3} \mathrm{OH}$

CGE

DOE

InEnTec

$\mathrm{k}$

LDRD

PLC

PNNL

$\mathrm{SNG}$

SOP

Syngas

TRC

WGS
Degrees Fahrenheit

Standard enthalpy change of reaction (units of joules). The enthalpy change that occurs in a system when one mole of reactant is transformed by a chemical reaction at 1 bar and $25^{\circ} \mathrm{C}$. Positive values indicate endothermic reactions, which require a continuous supply of energy from the surroundings to be sustained. Negative values indicate exothermic reactions, which release energy to the surroundings.

Residence time (a.k.a. space time, units of seconds); the time necessary to process one reactor volume of reactant based on entrance conditions. The residence time can be thought of as the average time feedstock molecules spend in the gasifier.

American Society for Testing and Materials

British thermal units

Methanol (often abbreviated $\mathrm{MeOH}$ )

Cold Gas Efficiency

U.S. Department of Energy

Integrated Environmental Technologies

Thermal conductivity in Btu- $\mathrm{ft} / \mathrm{hr}-\mathrm{ft}^{2}{ }^{\circ} \mathrm{F}$

Laboratory Directed Research and Development

Programmable Logic Controller

Pacific Northwest National Laboratory

Substitute natural gas

Standard operating procedure

Syngas is also known as synthesis gas. It is the name given to a gas mixture that contains varying amounts of carbon monoxide and hydrogen.

Thermal residence chamber

Water-gas shift 



\section{Contents}

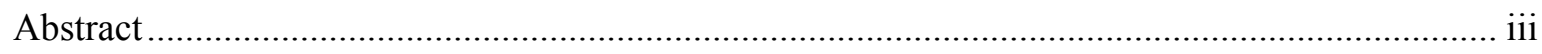

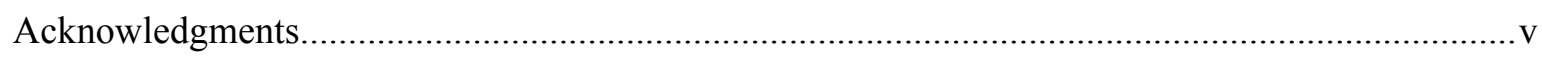

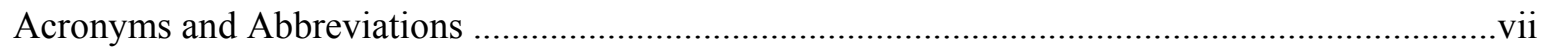

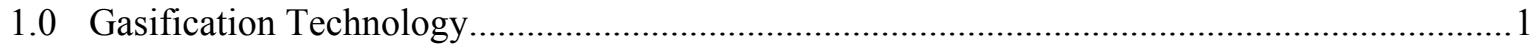

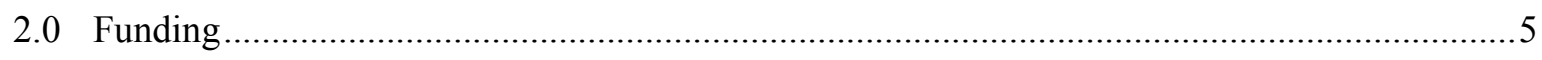

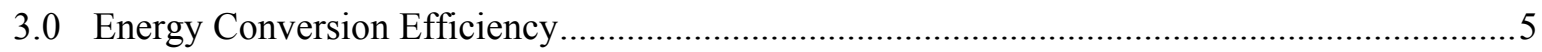

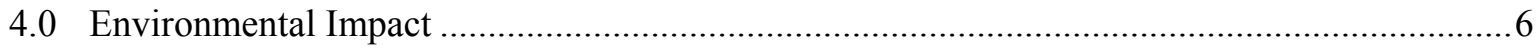

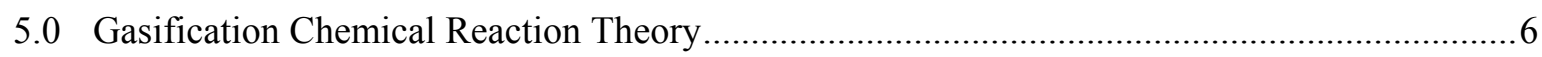

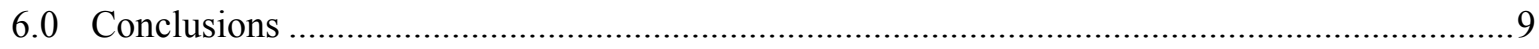

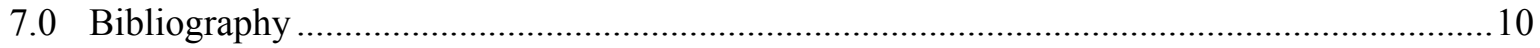

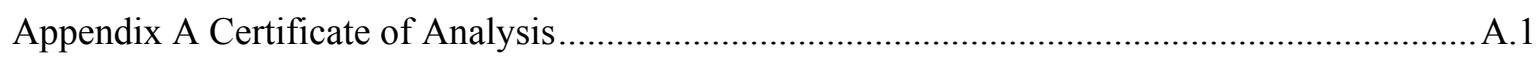




\section{Figures}

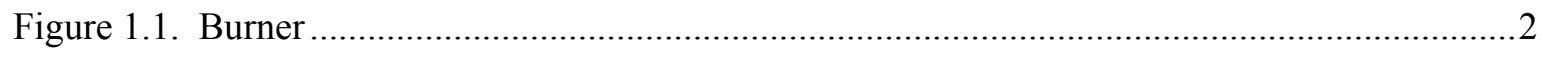

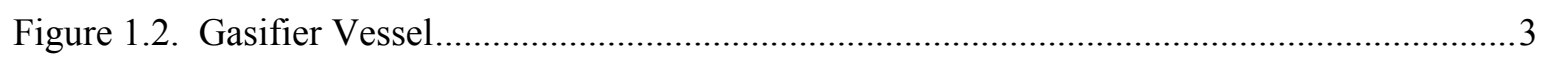

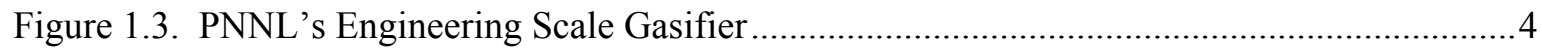




\subsection{Gasification Technology}

Gasification is a process for converting solid or liquid carbonaceous materials, such as coal, to a combustible product gas. The dominant chemical process is partial oxidation, in which the feedstock material reacts with a sub-stoichiometric amount of oxygen (and often with steam) to produce a synthesis gas (syngas) consisting primarily of hydrogen and carbon monoxide. An attractive feature of gasification is its ability to transform many different types of organic materials, including low-value waste and biomass, into a flexible-use, high-value product. In commercial applications, the gaseous products are typically combusted for heat or electricity generation, or used as starting materials for the synthesis of liquid fuels and chemicals.

PNNL's gasifier at Integrated Environmental Technologies (InEnTec) is a small entrained flow slagging gasifier of nominally $10 \mathrm{lb} / \mathrm{hr}$ of pulverized coal feed. Oxygen vapor from liquid dewars is used as the oxidant. The primary purposes of this gasifier are to 1) produce an internal slag layer to determine if its thickness could be determined by millimeter wave technology and 2) to produce syngas from coal for catalyst and materials testing. Thus the gasifier is not designed for fundamental studies of coal gasification.

The gasification vessel and associated equipment is designed for operation to 250 psig. However, limitations of the coal feed system, oxygen supply, syngas processing capability and safety concerns have limited operation to near atmospheric pressure.

In an entrained flow gasifier, finely ground coal feedstock particles undergo thermal decomposition, partial combustion, and reaction with steam and other gas components as they are dragged along with the self generated gas stream in co-current flow.

Dry, pulverized solid coal is fed from a small nitrogen purged screw feeder and a liquid fuel (methanol) are fed to a burner located at the top of the gasifier vessel by a hopper system with nitrogen push gas and a pump, respectively (see Figure 1.1). The burner serves to establish good

mixing between the fuel(s) and the oxygen, so that the gasification reactions take place in a dense cloud of very fine particles. (Methanol provides a reliable feed source that serves to attenuate temperature fluctuation in the gasifier caused by variability of the instantaneous coal feed rate from the hopper system.) 


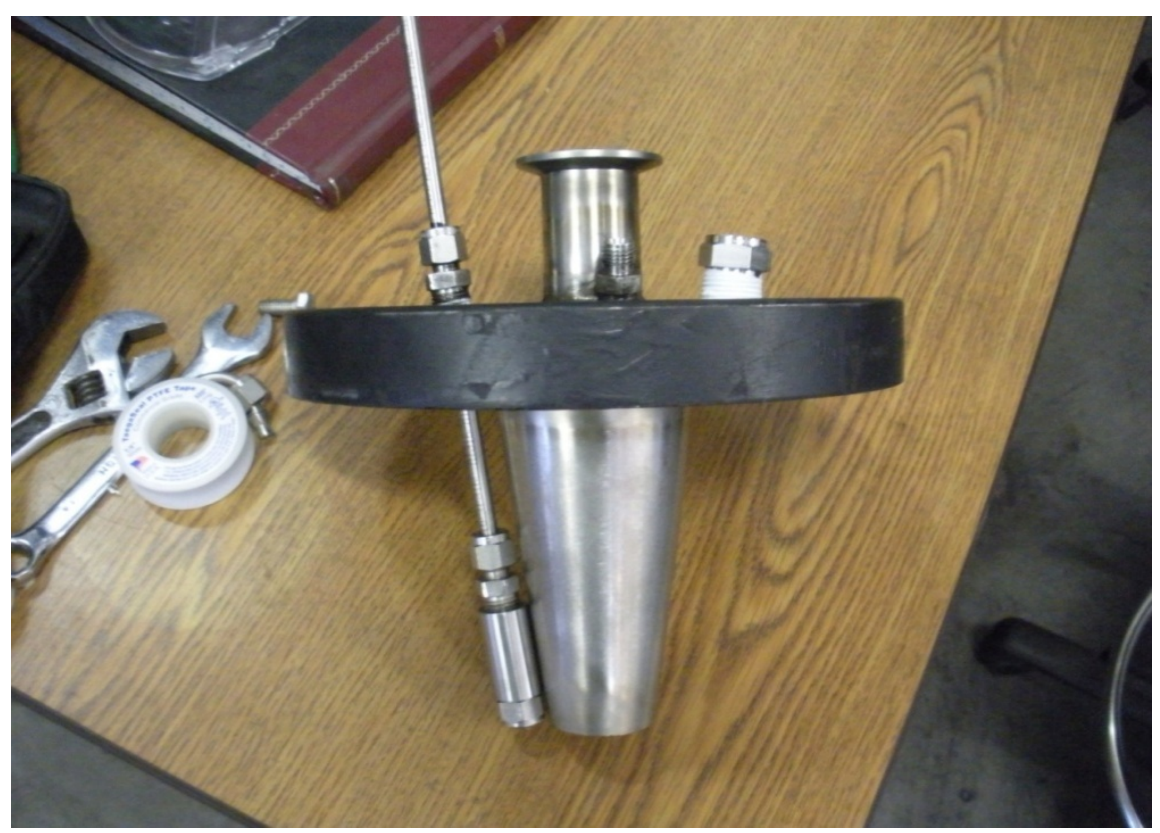

Figure 1.1. Burner

Below the burner, the gasifier vessel 3, 16" pipe flanged spool pieces bolted together to form a vessel approximately 9' tall (see Figure 1.2). The first two segments of the gasifier are lined with concentric layers of ceramic fiber blanket insulation, castable insulating refractory, and an interior dense castable ring, leaving an internal, empty cylindrical chamber in the center. The insulation and refractory layers protect the gasifier walls from high temperature and prevent excessive heat loss. The cylindrical chamber is designed to provide residence time for the coal to gasify and gas reactants to approach equilibrium at $250 \mathrm{psig}$ and $2500^{\circ} \mathrm{F}$. 


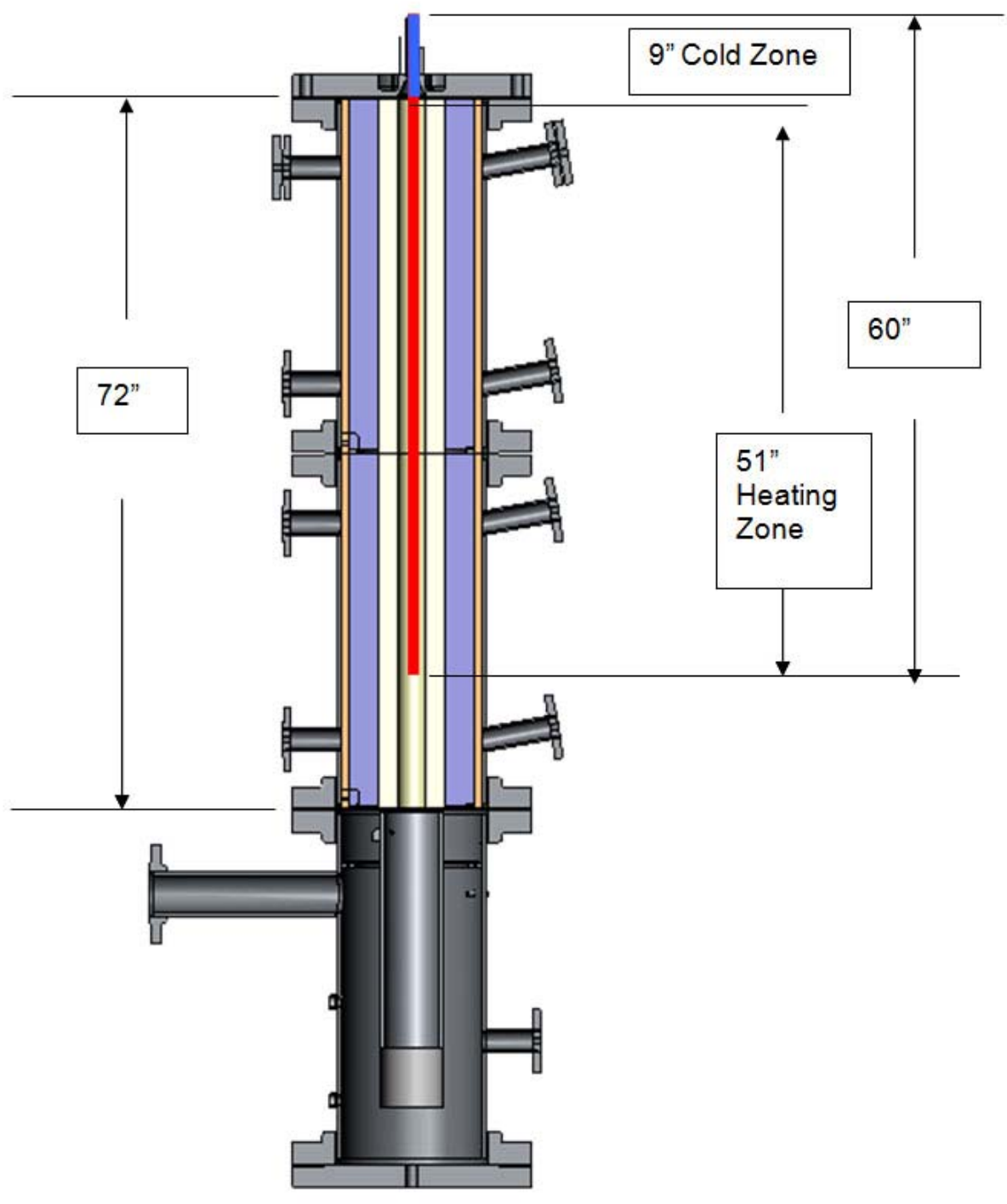

Figure 1.2. Gasifier Vessel

The gasifier is designed to react the coal feed at $2500^{\circ} \mathrm{F}$ which is above the melting point of the coal ash. The molten ash, composed primarily of silica and alumina minerals (slag) form a highly viscous layer on the inner wall of the gasifier, with liquid slag being solidified and then removed at the bottom of the gasifier. The ash fluid temperature estimated for the Pocahontas coal used in the PNNL gasifier is $2201{ }^{\circ} \mathrm{F}$ [6]. The Pocahontas coal used is a low sulfur seam coal from West Virginia. The coal was ground extremely fine for greater reactivity and conversion. For a certificate of analysis of the coal fed to the PNNL gasifier refer to Appendix A.

In the third section, water is sprayed through nozzles into the gas stream to rapidly lower its temperature and stop reaction. 

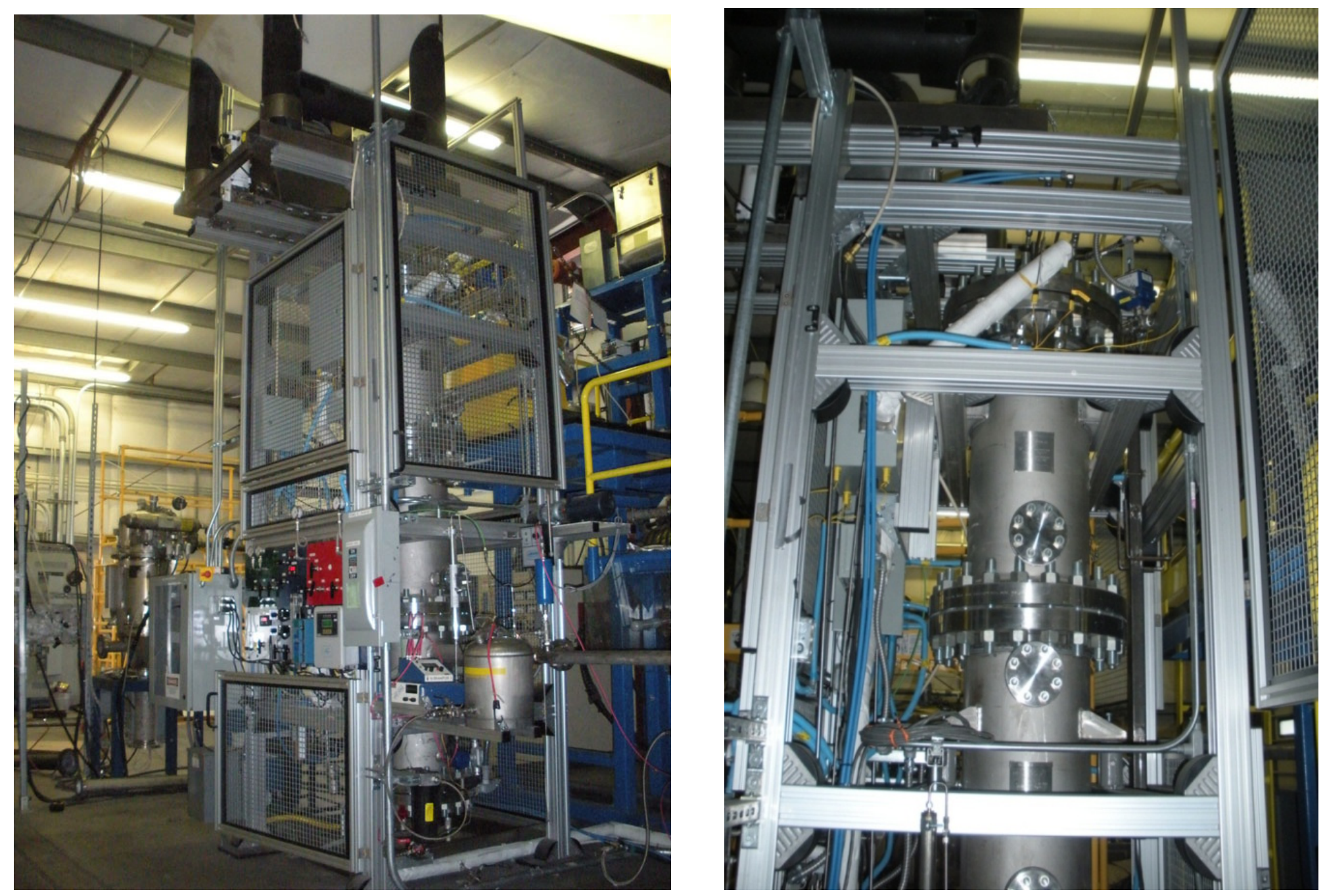

Figure 1.3. PNNL's Engineering Scale Gasifier 


\subsection{Funding}

The engineering scale gasifier project was internally funded by PNNL's Laboratory Directed Research and Development (LDRD) program. LDRD is work of a creative and innovative nature for the purpose of maintaining the scientific and technological vitality of the Laboratory and/or responding to new scientific or technological opportunities. The LDRD program allows the Laboratory to fund new and highly innovative research activities to enhance the ability of PNNL to address the future mission objectives of the U.S. Department of Energy (DOE). LDRD funding may be used for the following purposes:

- Develop new technologies and capabilities that are consistent with DOE and PNNL missions.

- Conduct experiments and analyses directed towards "proof of principle" or early determination of the utility of new scientific ideas, technical concepts, or devices that are related to DOE requirements and are likely to result in follow-on research.

- Conduct studies of new hypotheses, new concepts, or innovative approaches to scientific or technical problems.

- Enhance existing PNNL capabilities and develop new capabilities by providing creative research opportunities that allow staff to enter a new field of research, enhance the scientific stature, and/or facilitate collaborative research with university scientists. Conceptualize and conduct preliminary technical analysis of new experimental facilities or devices.

\subsection{Energy Conversion Efficiency}

A common way to measure gasifier performance is to calculate the cold gas efficiency:

$$
\eta_{c g}=\frac{m_{\mathrm{H}_{2}} L H V_{\mathrm{H}_{2}}+m_{\mathrm{CO}} L H V_{C O}+m_{\mathrm{CH}_{4}} L H V_{C H_{4}}}{m_{\text {coal }} L H V_{\text {coal }}} \times 100 \%
$$

where $\eta_{c g}$ is the cold gas efficiency, $m_{\mathrm{H}_{2}} m_{\mathrm{CO}}$, and $m_{\mathrm{CH}_{4}}$ are the product gas mass flows of hydrogen, carbon monoxide, and methane: and $L H V_{H_{2}}, L H V_{C O}$ and $L H V_{C_{4}}$ are the lower heating value of the corresponding compound. The lower heating value is the amount of heat energy released per unit mass of a substance when it is combusted and the latent heat of vaporization for the product water is excluded (as opposed to the higher heating value, which includes the heat of vaporization). The cold gas efficiency provides a simple way to compare the energy content of the combustible syngas constituents to that of the original coal feedstock (plus methanol) from which they were derived.

Extensive energy analysis was not performed for the gasifier because its primary purpose is to generate coal syngas for development of materials, catalysts, and instrumentation useful in converting coal into electricity and chemicals and not for coal gasification research as previously stated. Therefore the equipment and instrumentation necessary to accurately quantify the gasifier conversion efficiency is absent. 


\subsection{Environmental Impact}

Before constructing a gasifier facility, PNNL considered the environmental impact. The syngas product stream from the PNNL gasifier is sent through existing equipment maintained by InEnTec for treatment of syngas produced by their plasma enhanced melter (PEM) waste-toenergy technology. The syngas is quenched with water at the bottom of the gasifier vessel. InEnTec disposes of the quench water via approved regulatory disposal paths. Next, the syngas passes through a thermal residence chamber (TRC), which is a refractory-lined empty steel vessel. The TRC provides additional cooling for the syngas. The syngas exits the TRC and moves into a packed column scrubber, which removes acid gases $\left(\mathrm{CO}_{2}\right.$ and $\left.\mathrm{H}_{2} \mathrm{~S}\right)$ and particulates. After passing through the scrubber, the gas is directed through a high efficiency particulate air (HEPA) filter. The cleaned syngas is then released to the atmosphere through a stack.

\subsection{Gasification Chemical Reaction Theory}

As coal, or any other carbonaceous feedstock enters a gasifier, its temperature increases and any moisture present in the material quickly escapes to the gas phase. Pyrolysis (also known as devolatilization) occurs as the feedstock temperature continues to increase. During pyrolysis, the feedstock undergoes heat-induced decomposition, which results in the liberation of volatile constituents to the gas phase. Volatile matter can include: $\mathrm{H}_{2}, \mathrm{CO}_{2}, \mathrm{CO}, \mathrm{CH}_{4}, \mathrm{H}_{2} \mathrm{~S}, \mathrm{NH}_{3}$, various short-chain hydrocarbons, and a small amount of aromatic hydrocarbons and tars [5]. In general, the gas phase has greater hydrogen, oxygen, and sulfur content than the original feed material, while the remaining solid material (char) is a mixture of carbon-rich organics and any minerals that were present in the feedstock.

The reactions of pyrolysis and gasification are endothermic (positive value), and require a continual input of energy from the surroundings to proceed. This energy is provided by combusting some of the feedstock and/or char and volatiles. Exothermic reactions produce heat and are represented with a negative value. The majority of the compressed oxygen fed to the gasifier is consumed in the following combustion reactions:

$$
\begin{aligned}
C(s)+\mathrm{O}_{2}(g) & \rightarrow \mathrm{CO}_{2}(g) & \Delta H^{\circ} & =-393.5 \mathrm{~kJ} / \mathrm{mo} \\
C(s)+\frac{1}{2} \mathrm{O}_{2}(g) & \rightarrow \mathrm{CO}(g) & \Delta H^{\circ} & =-110.5 \mathrm{~kJ} / \mathrm{mol} \\
\mathrm{H}_{2}(g)+\frac{1}{2} \mathrm{O}_{2}(g) & \rightarrow \mathrm{H}_{2} \mathrm{O}(g) & \Delta H^{\circ} & =-241.8 \mathrm{~kJ} / \mathrm{mol}
\end{aligned}
$$

Energy from the combustion reactions is used to drive the gasification reactions, which result in the generation of synthesis gas.

$$
2 \mathrm{CH} 3 \mathrm{OH}(\mathrm{l})+3 \mathrm{O}_{2}(g) \rightarrow 2 \mathrm{CO}_{2}(g)+4 \mathrm{HO}_{2}(g) \quad \Delta H^{\circ}=-760 \mathrm{~kJ} / \mathrm{mol}
$$

Gasification reactions can be solid-gas phase, in which case carbon in the char reacts with steam, carbon dioxide, and hydrogen present in the gasifier. In addition, gas-gas phase reactions 
(e.g., water-gas shift and methanation) occur that alter the composition of the final syngas product. The major solid-gas phase gasification reactions are as follows:

$$
\begin{array}{rr}
C(s)+\mathrm{H}_{2} \mathrm{O}(g) \rightarrow \mathrm{CO}(g)+\mathrm{H}_{2}(g) & \Delta H^{\circ}=131.3 \mathrm{~kJ} / \mathrm{mol} \\
C(s)+2 \mathrm{H}_{2} \mathrm{O}(g) \rightarrow \mathrm{CO}_{2}(g)+2 \mathrm{H}_{2}(g) & \Delta H^{\circ}=90.1 \mathrm{~kJ} / \mathrm{mol} \\
\mathrm{C}(\mathrm{s})+\mathrm{CO}_{2}(g) \rightarrow 2 \mathrm{CO}(g) & \Delta H^{\circ}=172.5 \mathrm{~kJ} / \mathrm{mol} \\
\mathrm{C}(\mathrm{s})+2 \mathrm{H}_{2}(g) \rightarrow \mathrm{CH}_{4}(g) & \Delta H^{\circ}=-74.8 \mathrm{~kJ} / \mathrm{mol}
\end{array}
$$

Reactions (5.4) and (5.5) are known as water-gas reactions and are the dominant gasification reactions if steam is fed to the gasifier [5]. Reaction (5.6) is the endothermic direction of the Boudouard reaction, which is favored over its reverse direction by the high temperatures inside the gasifier. Reaction (5.7), known as hydrogasification, is employed extensively by gasification processes, where methane is the desired end product for the production of substitute natural gas (SNG). This reaction, which is exothermic, proceeds very slowly unless performed under high pressures $[5,13]$.

An important gas phase reaction concerned with the concentration of hydrogen in the synthesis gas product stream is the water-gas shift (WGS) reaction:

$$
\mathrm{CO}(g)+\mathrm{H}_{2} \mathrm{O}(g) \rightarrow \mathrm{CO}_{2}(g)+\mathrm{H}_{2}(g) \quad \Delta H^{\circ}=-41.2 \mathrm{~kJ} / \mathrm{mol}
$$

The WGS reaction is reversible; the forward reaction shown here is often desired if the syngas is to be purified for use in hydrogen fuel cells. The WGS reaction simultaneously increases hydrogen concentration while decreasing the concentration of carbon monoxide, a poison for the platinum catalysts used in many fuel cells [13]. Although the reaction occurs naturally within the gasifier, the syngas product is sent through a downstream reactor, where conditions (additional steam injection and use of a catalyst) can be adjusted to maximize conversion if fuel cell grade hydrogen is desired. Another important gas phase reaction that affects the balance between methane concentration and that of $\mathrm{CO}$ and $\mathrm{H}_{2}$ is the methanation reaction:

$$
\mathrm{CO}(g)+3 \mathrm{H}_{2}(g) \rightarrow \mathrm{CH}_{4}(g)+\mathrm{H}_{2} \mathrm{O}(\mathrm{g}) \quad \Delta H^{\circ}=206.1 \mathrm{~kJ} / \mathrm{mol}
$$

An examination of the thermodynamic and equilibrium characteristics of the reactions presented above reveals that the temperature and pressure within the gasifier can be adjusted to favor production of syngas with an increased $\mathrm{CH}_{4}$ content or a maximum concentration of $\mathrm{H}_{2}$ and CO. The methane-producing reactions (5.7) and (5.9) are product-favored at lower temperatures and higher pressures, as predicted by Le Chatelier's principle. Conversely, formation of $\mathrm{H}_{2}$ and $\mathrm{CO}$ is favored at higher temperatures and lower pressures. In addition to temperature and pressure, the ratio of oxygen-to-steam fed to the gasifier can be adjusted to alter the syngas composition. If steam is the dominant oxidizing agent, increased levels of $\mathrm{H}_{2}$ and $\mathrm{CH}_{4}$ will be present in the product gas. High oxygen-to-steam feed ratio results in increased formation of $\mathrm{CO}$ and $\mathrm{CO}_{2}[5]$. 
The PNNL gasifier is operated at close to atmospheric pressure and with a temperature gradient of approximately $1,275^{\circ} \mathrm{C}\left(2,300^{\circ} \mathrm{F}\right)$ at the top thermocouple down to $450^{\circ} \mathrm{C}\left(850^{\circ} \mathrm{F}\right)$ at the bottom thermocouple [11]. These conditions minimize $\mathrm{CH}_{4}$ formation. In addition to coal, methanol is an important part of the fuel feed to the PNNL gasifier. Methanol undergoes heatinduced chemical decomposition into carbon monoxide and hydrogen, as given by the following reaction:

$$
\mathrm{CH}_{3} \mathrm{OH}(\mathrm{l}) \rightarrow \mathrm{CO}(\mathrm{g})+2 \mathrm{H}_{2}(\mathrm{~g}) \quad \Delta H^{\circ}=128.1 \mathrm{~kJ} / \mathrm{mol}
$$

This reaction is endothermic, and relies on heat generated from the exothermic combustion reactions (5.1) through (5.3) to be sustained and avoid quenching the reactor. The methanol and oxygen react quickly followed by the gas-solid reactions.

The PNNL gasifier is now being operated with only an oxygen feed, as opposed to both oxygen and superheated steam. Steam was removed to increase flame temperature inside the gasifier. When steam was removed from the feed, less methane was formed in the syngas. Also, the hydrogen to carbon monoxide ratio was reduced. Sufficient steam was generated by the combustion of methanol that additional steam was not necessary. 


\subsection{Conclusions}

At the conclusion of commissioning, proof of principle was achieved for a modified burner that delivers coal and methanol to the gasifier (see Figure 1.1). Bench testing for fuel constituent mixing was completed, followed by successful demonstration in the gasifier vessel itself. As the project progresses, future gasifier runs will be prioritized and aligned with PNNL research objectives. These primary future objectives include providing syngas to researchers by pressurizing and bottling samples and by ensuring syngas composition is appropriate for customer needs. 


\subsection{Bibliography}

1. Baxter, Larry. “Ash Fusion Temperatures.” Energy Laboratory Web Site. Brigham Young University, 2001. Web. Jan. 2009.

http://www.et.byu.edu/ larryb/Ash\%20Fusion\%20Temperatures 1.html

2. Chen, Lei, Nolan, Rane, and Shakeel Avadhany. "Thermodynamic Analysis of Coal-to-SNG process". Massachusetts Institute of Technology, May 14, 2009. Web. Jan. 2010.

www.mit.edu/people/leichen/Thermodynamic Analysis of the coal to SNG process.pdf

3. “Coal Gasification.” EcoGeneration Solutions, LLC, 2002. Web. Jan. 2009. http://www.cogeneration.net/Coal-Gasification.htm

4. "Coal and Power Systems: Gasification." National Energy Technology Laboratory (NETL), n.d. Web. Jan. 2009. http://www.netl.doe.gov/technologies/coalpower/gasification/

5. “Gasification.” Wikipedia, the free encyclopedia, n.d. Web. Jan. 2009. http://en.wikipedia.org/wiki/Gasification

6. Harbison-Walker Thermal Modeling Web Tool. ANH Refractories Company, 2005. Web. 18 Sep 2009. http://www.hwr.com/

7. Higman, Christopher, and Maarten van der Burgt. Gasification. $2^{\text {nd }}$ ed. Burlington, MA: Elsevier, Inc., 2008. Print.

8. InEnTec Website. InEnTec LLC, 2009. Web. Jan. 2009. http://www.inentec.com/

9. Krause, Theodore. "Water-Gas Shift Catalysis." DOE Hydrogen Program: FY 2005 Progress Report, 2005. Web. 24 Jan. 2010. http://www.hydrogen.energy.gov/pdfs/progress05/vii_f_1_krause.pdf

10. "Occupational Safety and Health Guideline for Coal Dust (Greater than or Equal to $5 \% \mathrm{SiO}_{2}$ )." Occupational Safety \& Health Administration, n.d. Web. Jan. 2009. http://www.osha.gov/SLTC/healthguidelines/coaldust-greater5percentsio2/recognition.html

11. Pacific Northwest National Laboratory. PNNL Gasification Project: Commissioning SOP (Methanol + Coal). Document Number: ECI-Me:Coal 1. Rev. A. Richland, WA: Pacific Northwest National Laboratory, 2009. Print.

12. "Recovery Act - Integrated Energy System with Beneficial CO2 Use." United States Department of Energy, Office of Fossil Energy Project Fact Sheet, 2009. Web. 24 Jan. 2010. http://fossil.energy.gov/fred/feprograms.jsp?prog=all\&state $=\mathrm{AZ}$

13. Rezaiyan, John, and Nicholas P. Cheremisinoff. Gasification Technologies: A Primer for Engineers and Scientists. Boca Raton, FL: CRC Press, 2005. Print.

14. Speight, James G. The Chemistry and Technology of Coal. $2^{\text {nd }}$ ed. Laramie, WY: CD\&W Inc., 1994. Print. 
Appendix A

Certificate of Analysis 



\section{Appendix A - Certificate of Analysis}

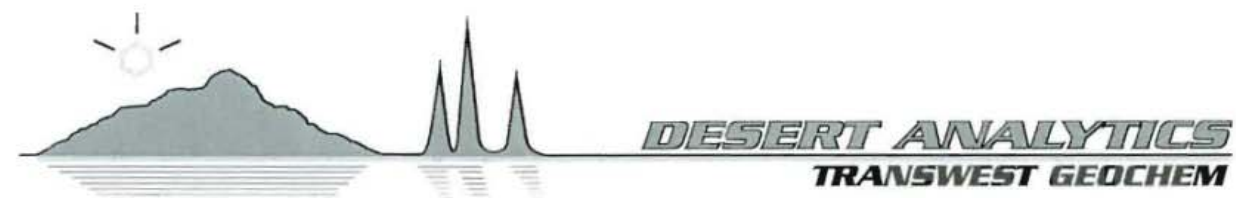

August 162007

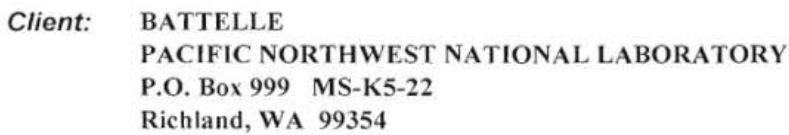

Attn: $\quad$ Michael G. Dodson

$\begin{array}{lll}\text { Project: } & \text { Date Received: } & \text { August 14, } 2007\end{array}$

Certificate of Analysis

\begin{tabular}{|c|c|c|c|c|c|}
\hline Analyses & Method & units & $\begin{array}{c}1 \\
\text { DA07-7482 }\end{array}$ & $\begin{array}{c}\# 131 \\
\text { DA07-7483 }\end{array}$ & $\begin{array}{c}\# 132 \\
\text { DA07-7484 } \\
\end{array}$ \\
\hline Proximate Analysis & D3172-89 & & & & \\
\hline Moisture & & $\%$ & 0.52 & 0.51 & 0.50 \\
\hline Volatile Matter & & $\%$ & 16.55 & 16.55 & 17.30 \\
\hline Fixed Carbon & & $\%$ & 72.60 & 72.64 & 71.88 \\
\hline Ash & & $\%$ & 10.86 & 10.81 & 10.81 \\
\hline Ultimate & D3176-89 & & & & \\
\hline Carbon & & $\%$ & 79.17 & 78.74 & 79.53 \\
\hline Hydrogen & & $\%$ & 4.32 & 4.06 & 4.06 \\
\hline Nitrogen & & $\%$ & 1.57 & 1.60 & 1.58 \\
\hline Oxygen & & $\%$ & 4.10 & 4.50 & 3.94 \\
\hline Sulfur & & $\%$ & 0.583 & 0.618 & 0.590 \\
\hline
\end{tabular}

2-3 Day Rush

Notes:

Values reported on an Moisture Free basis

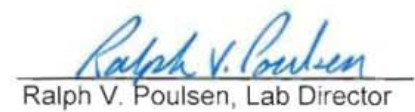

3860 S. Palo Verde Rd.

Suite 303

Tucson, AZ 85714

520.623.3381

Page 1 of 1

Rpt-7482 Battelle Dodson, 8/16/2007 



\section{Distribution}

No. of

Copies

1 Local Distribution

Pacific Northwest National Laboratory

$\begin{array}{ll}\text { D Reid } & \text { PDF } \\ \text { MD Bearden } & \text { PDF } \\ \text { JE Cabe } & \text { PDF } \\ \text { TJ Samuel } & \text { PDF } \\ \text { RJ Robertus } & \text { PDF } \\ \text { ML Elliot } & \text { PDF }\end{array}$

Distr.1 




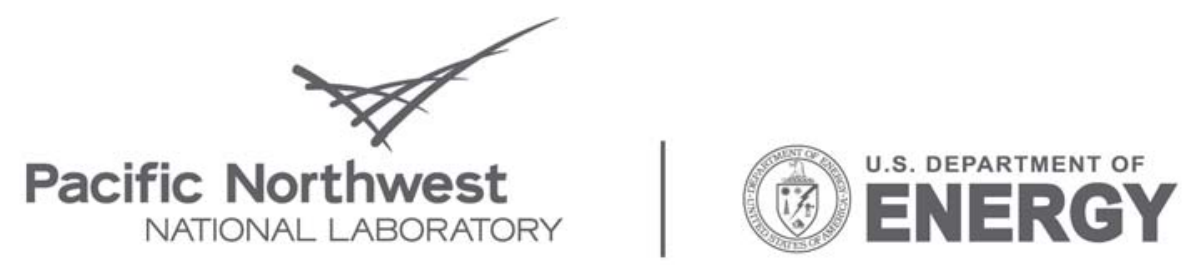

Proudly Operated by Battelle Since 1965

902 Battelle Boulevard

P.O. Box 999

Richland, WA 99352

1-888-375-PNNL (7665)

www.pnl.gov 